\title{
Preventing Bar-Related Complications for Chest Wall Deformities
}

\section{Göğüs Duvarı Deformitelerinde Bar İlişkili Komplikasyonların Önlenmesi}

\author{
DHuseyin Yildiran', DGuven Sadi Sunam1 \\ 1 Selçuk University, Medical Faculty, Thoracic Surgery Department, Konya, Turkey
}

\begin{abstract}
Aim: Nuss procedure for pectus excavatum and Abramson procedure for pectus carinatum are used as minimally invasive methods for surgical treatment of chest wall defomities. The aim of this study is to investigate the causes of bar-related complications, and to present technical details of their management.
\end{abstract}

Material and Method: Patients who underwent minimally invasive correction surgery with the diagnosis of pectus excavatum and pectus carinatum between 2011-2020 in our clinic were included in this study. The surgical treatments, bar related complications, and follow-up records of patients were recorded and analyzed retrospectively.

Results: 141 patients with a mean age of $16.08 \pm 4.38$ were included in the study. Postoperative bar-related complications were encountered in 28 (19.8\%) of all patients. There were no life-threatening early or late complications. The most common complication was skin reaction in 7 (4.9\%) cases.

Conclusion: Bar-related complications are problems that can cause morbidity and disrupt patient comfort, thus management of complications should be focused on.

Keywords: Complication, pectus carinatum, pectus excavatum, surgery
Öz

Amaç: Göğüs duvarı deformitelerinin cerrahi tedavisinde minimal invaziv yöntemler olarak pektus ekskavatumda Nuss prosedürü ve pektus karinatumda Abramson prosedürü kullanılmaktadır. Bu çalışmanın amacı, bar ile ilişkili komplikasyonların nedenlerini araştırmak ve tedavilerinin teknik ayrıntılarını sunmaktır.

Gereç ve Yöntem: Kliniğimizde 2011-2020 yılları arasında pektus ekskavatum ve pektus karinatum tanısı ile minimal invaziv düzeltme ameliyatı geçiren hastalar bu çalışmaya dahil edildi. Hastaların cerrahi tedavileri, bara bağlı komplikasyonlar ve takip kayıtları kaydedildi ve geriye dönük olarak analiz edildi.

Bulgular: Çalışmaya yaş ortalaması 16.08 \pm 4.38 olan 141 hasta dahil edildi. Tüm hastaların 28'inde (\% 19,8) ameliyat sonrası bar ile ilişkili komplikasyonlarla karşış̧ıldı. Yaşamı tehdit eden erken veya geç komplikasyon olmadı. En sık görülen komplikasyon 7 (\% 4.9) vakada cilt reaksiyonuydu.

Sonuç: Bara bağlı komplikasyonlar, morbiditeye neden olabilen ve hasta konforunu bozabilen sorunlardır, bu nedenle komplikasyonların önlenmesine ve yönetimine dair daha fazla odaklanılmalıdır.

Anahtar Kelimeler:Cerrahi, komplikasyon, pektus ekskavatum, pektus karinatum 


\section{INTRODUCTION}

Pectus excavatum (PE) and pectus carinatum (PC) are the most common congenital chest wall deformities. In both these deformities, the pathology includes the depression or protrusion of the sternum and the shape anomalies in the adjacent cartilage ribs. The aim of the treatment is to break the resistance of the bone and cartilage structure and restore the normal appearance of the position of the sternum and cartilaginous ribs by the effect from the inside or outside. Nuss procedure for PE and Abramson procedure for PC are used as minimally invasive methods for the last 20 years. ${ }^{[1,2]}$ Various modifications of these two methods have been described, and the main material providing correction is the "pectus bar".

The most common complaint in chest wall deformities is cosmetic complaints. ${ }^{[3]}$ For this reason, after a minimally invasive surgery, the results should be effective and the complications that may develop should be minimal and controllable.

Therefore, it is important to prevent and manage bar-related complications. With ten years of experience in this surgery, many technical details are considered in our clinic. Although there are many articles related to complications in the literature, there are limited number of publications that address barrelated complications only.

The aim of this study is to investigate the causes of bar-related complications in patients treated with pectus deformity using bars, and to present technical details of their management.

\section{MATERIAL AND METHOD}

One hundred forty-one patients who underwent minimally invasive correction surgery with the diagnosis of PE and PC between 2011-2020 in our clinic were included in the study after obtaining the approval of the local ethics committee (Approval No: 2020/246) and this study was designed in accordance with the principles of the Declaration of Helsinki. The patients' age, gender, complaints of admission to the hospital, chest wall deformity (PE/PC/asymmetric/symmetric), surgical method (Nuss/Abramson), hospital stay, bar-related complications, bar removal times were analyzed retrospectively. Non-barspecific postoperative complications such as pneumothorax, pneumonia, and incision pain were not included in the study.

\section{Surgical methods}

\section{Pectus excavatum (Nuss procedure)}

Bar length was planned using a sizer before surgery. After the bar length was determined, planning was made on the skin: The most depressed place of the sternum was marked and the xiphoid was determined. The line where the introducer will advance and the intercostal space where it will enter the right hemithorax, and the intercostal space where it will exit from the left hemithorax to the subcutaneous tissue were determined. The skin was incised. A random-pedicled muscle flap from the pectoral muscle was elevated. Before the introducer entered the right hemithorax, pressure was created in the thorax with medical air and the lung collapsed. For this purpose, medical air at $8 \mathrm{~cm}-\mathrm{H} 2 \mathrm{O}$ pressure was used with an insufflator. In order to create the cleavage in the anterior mediastinum where the introducer will pass, firstly the pleura was opened with the introducer and advanced subpleurally, and emphysema was achieved in the subpleural area and mediastinum thanks to the given medical air (Figure 1). Thanks to the marks on the skin, while watching the introducer from the monitor, it was followed through the thoracic wall. While advancing the introducer, the curved end was always kept in contact with the bone structure and blunt dissection was continued with gentle movements from the sternum to the mediastinum. When the anterior mediastinum was opened, the pneumomediastinum was created and the dissected area was expanded, and passed from this cleavage to the left hemithorax (Figure 2). An incision was made to allow subxiphoidal finger dissection in cases with previous sternotomy or mediastinal adhesions due to another intrathoracic surgery or disease. For mixed-type pectus deformities, resection of protruding cartilage ribs and wedge osteotomy to the sternum were performed. The bar was placed through the tunnel created in the anterior mediastinum, and a stabilizer was placed at one end of the bar. One common stabilizer was used at each of the two bars ends in patients with double layer bars. The bar was placed in the ribs both with a stabilizer and by videothoracoscopic observation around the rib; then bar and stabilizer were fixed with absorbable sutures. Bilateral bar ends and the stabilizer were covered with a previously harvested muscle flap.

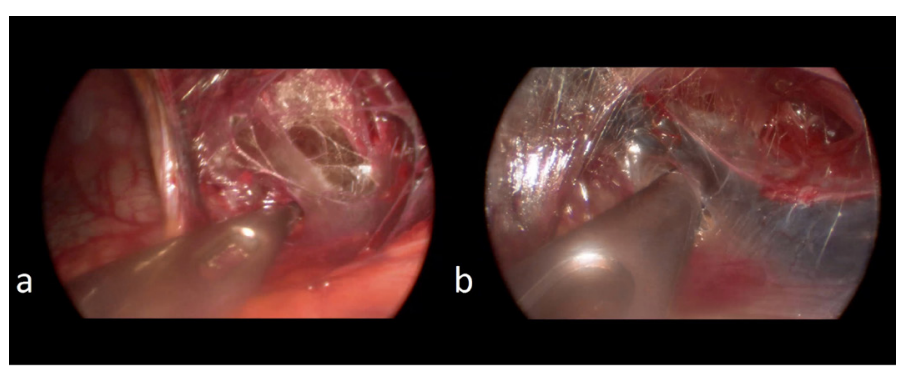

Figure 1. a. The dissection of subpleural area. b. The subpleural emphysema and pneumomediastinum.

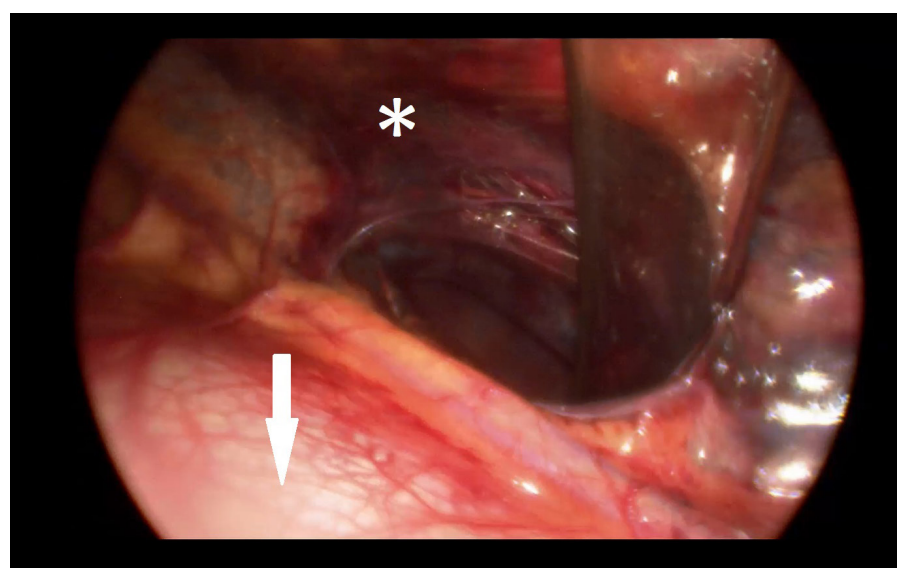

Figure 2. Widening the retrosternal dissection after the introducer passes to the left hemithorax (Arrow: pericardium, star: sternum). 


\section{Pectus carinatum (Abramson procedure)}

Bar length was measured preoperatively by applying pressure to the sternum to correct protrusion. A bar size 5-mm shorter than the measured amount was used. Random-pedicled flaps from bilateral pectoral muscle were harvested following skin incision. Bars were passed through the front of the sternum and subcutaneous tunnel and fixed with wire sutures to the bilateral ribs. A double layer bar was applied in cases with high sternum resistance. Wire sutures were passed around the upper and lower ribs and first a stabilizer, then a bar was placed. For double layer bars, one common stabilizer was used on each side and these were fixed to the ribs with wire sutures (Figure 3). They were covered with muscle flaps.

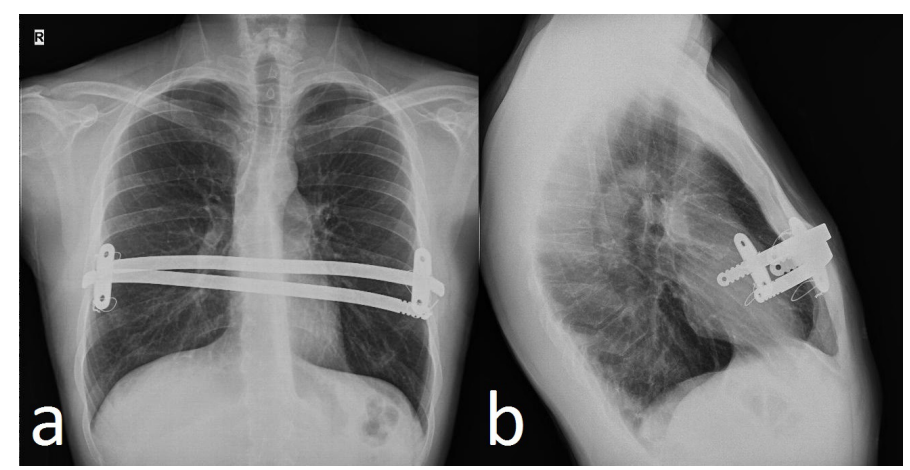

Figure 3. The double-layer bar in pectus carinatum, a. Posteroanterior and b. Lateral view.

\section{Approach to the patient after the bar is fixed}

In order to prevent pitting on the skin due to dermal shrinkage, the advancement of the bar was made at the deep fascia level. The patients were immobilized on the day of operation. All patients were mobilized in the room three times a day on the postoperative first day, and normal mobilization was initiated from the postoperative second day.

There was no need for follow-up in the intensive care unit for any patient. Intravenous paracetamol and tramadol were used as analgesics. Postoperative follow-ups were done on the $15^{\text {th }}$ day, $1^{\text {st }}$ month, $3^{\text {rd }}$ month and after 6 months.

It was planned to remove the bar after 24 months in PE cases and 12 months in PC cases.

The correlation between age and length of hospital stay, age and complications, symmetry of the deformity and complication rates, age and duration of bar removal, complications and duration of bar removal were investigated. The correlation between Haller index and complications was investigated in patients with PE deformity. Complication rates and bar removal times were compared statistically between $\mathrm{PE}$ and PC.

\section{Statistical method}

Statistical calculations were made using SPSS 21.0. Pearson Correlation test, Chi-square test and independent sample t-test were used.

\section{RESULTS}

One hundred forty-one patients (96 PE and $45 \mathrm{PC}$ ) with a mean age of $16.08 \pm 4.38$ were included in the study. Of the 120 males and 21 females, 67 had asymmetrical and 74 symmetrical deformities (Table 1).

\begin{tabular}{|c|c|c|c|}
\hline & PE (n-\%) & PC (n-\%) & Total (n-\%) \\
\hline & $96(68.1 \%)$ & 45 (31.9\%) & $141(100 \%)$ \\
\hline Male & $78(55.3 \%)$ & $42(29.8 \%)$ & $120(85.1 \%)$ \\
\hline Female & $18(12.8 \%)$ & $3(2.1 \%)$ & 21 (14.9\%) \\
\hline Asymmetric deformity & $42(29.8 \%)$ & $25(17.7 \%)$ & $67(47.5 \%)$ \\
\hline Symmetric deformity & $54(38.3 \%)$ & $20(14.2 \%)$ & $74(52.5 \%)$ \\
\hline Age (mean-year) & $16.46 \pm 5$ & $15.26 \pm 2.42$ & $16.08 \pm 4.38$ \\
\hline
\end{tabular}

The reason for admission to the hospital was cosmetic complaints in all (100\%) patients with PC and 75 (78.1\%) patients with PE (Table 2).

Table 2. Complaints of patients while hospital admittion.

\begin{tabular}{lc} 
Complaints & $\mathbf{n}(\%)$ \\
\hline Patients & \\
Pectus excavatum & $75(53.2 \%)$ \\
Cosmetic & $12(8.5 \%)$ \\
Dyspnea & $4(2.8 \%)$ \\
Palpitation & $3(2.1 \%)$ \\
Chest pain & $1(0.7 \%)$ \\
Reccurent pneumonia & $1(0.7 \%)$ \\
Syncope & \\
Pectus carinatum & $45(31.9 \%)$ \\
Cosmetic &
\end{tabular}

Haller index was calculated as $3.67 \pm 1.6$ in cases with PE.

Nuss procedure was performed for PE and, Abramson procedure was performed to $\mathrm{PC}$ patients (Table $\mathbf{3}$ ).

\begin{tabular}{lc} 
Table 3. The surgical approaches. & \\
\hline Characteristics of Surgical Procedures & $\mathbf{n}(\%)$ \\
\hline Pectus excavatum & $96(68.1 \%)$ \\
Correction with single bar & $85(60.3 \%)$ \\
$\quad$ Ravitch + Nuss approach & $2(1.4 \%)$ \\
$\quad$ Subxyphoid dissection & $3(2.1 \%)$ \\
$\quad$ Simultaneous lobectomy (CCAM) & $1(0.7 \%)$ \\
$\quad$ Simultaneous wedge resection (Hamartoma) & $1(0.7 \%)$ \\
Correction with double parallel bar & $2(1.4 \%)$ \\
Correction with double layer bar & $2(1.4 \%)$ \\
Pectus carinatum & $45(31.9 \%)$ \\
Correction with single bar & $43(30.5 \%)$ \\
$\quad$ Simultaneous thoracal sympathectomy & $1(0.7 \%)$ \\
Correction with double layer bar & $1(0.7 \%)$
\end{tabular}


The average length of hospital stay was recorded as $4.41 \pm 1.28$ days in all patients. This period was $4.55 \pm 1.16$ and $4.13 \pm 1.47$ days in patients with $\mathrm{PE}$ and $\mathrm{PC}$, respectively.

It was determined that there is a $22 \%$ weak positive correlation and significant difference between the age of the patients included in the study and the duration of hospitalization. (sig. $=0.009 \& \mathrm{It} ; \mathrm{p}$-value $=0.05$ ). It was found that as the age increased, the length of hospital stay increased.

In 103 patients, pectus bars were removed (73\%) and the mean bar removal time was calculated as $24.46 \pm 10.67$ months. The mean duration of bar removal in PE and PC patients was 27.29 $\pm 9.7(n=75)$ months and 16.89 $\pm 9.5(n=28)$ months, respectively, and a significant difference was found between the two groups (sig. $=0.000<\mathrm{p}$-value: 0.05 ).

The mean age of the cases whose bars were removed was $15.55 \pm 4.23$ years. There was no correlation between age and duration of bar removal (months) (sig. $=0.370>p$-value $=0.05$ ).

Postoperative bar-related complications were encountered in 28 (19.8\%) of all patients. There were no life-threatening early or late complications. The most common complication was skin reaction in 7 (4.9\%) cases (Figure 4, Table 4). The mean age of patients without complications and with complications was $15.71 \pm 4.21$ and $17.61 \pm 4.81$, respectively. It was found that there was a statistically significant difference between the two groups and the complication rate increased as the age increases (sig. $=0.040<p$-value $=0.05$ ).

Complication rates in patients with asymmetrical and symmetrical deformities were $22.4 \%$ and $17.6 \%$, respectively. There was no statistically significant difference between the two groups (sig. $=0.474>p$-value $=0.05$ ).

Table 4. The postoperative bar-related complications

\begin{tabular}{lccc}
\hline Complications & $\mathbf{n}(\%)$ & \multicolumn{2}{c}{ Management } \\
\hline Pectus excavatum & $96(100 \%)$ & Non-surgical & Surgical \\
Skin reaction & $3(3.1 \%)$ & 1 & 2 \\
Cartilage destruction & $3(3.1 \%)$ & - & - \\
Bar rotation & $2(2 \%)$ & - & 2 \\
Bar dislocation & $2(2 \%)$ & - & - \\
Chronic pain & $2(2 \%)$ & - & 2 \\
Bar migration & $1(1 \%)$ & - & - \\
Pericardial effusion & $1(1 \%)$ & 1 & - \\
Pleural effusion & $1(1 \%)$ & 1 & - \\
Bar exposition & $1(1 \%)$ & - & 1 \\
TOTAL & $16(16.7 \%)$ & 3 & 7 \\
Pectus carinatum & $45(100 \%)$ & Non-surgical & Surgical \\
Skin reaction & $4(8.8 \%)$ & 2 & 2 \\
Bar dislocation & $3(6.6 \%)$ & - & 2 \\
Bar exposition & $3(6.6 \%)$ & 2 & 1 \\
Chronic pain & $1(2.2 \%)$ & - & 1 \\
Wire exposition & $1(2.2 \%)$ & - & 1 \\
TOTAL & $12(26.7 \%)$ & 4 & 7 \\
\hline
\end{tabular}

The average Haller index of PE patients with and without complications was found to be $4.70 \pm 2.34$ and $3.47 \pm 1.34$, respectively. There was a statistically significant difference between these two groups (sig. $=0.047<p$-value $=0.05$ ).

The mean bar removal time for patients with and without complications was found to be $17.17 \pm 12.28$ months and $26.68 \pm 9.12$ months, respectively. There was a significant difference between the two groups (sig. $=0.001<p$-value $=0.05$ ). Complication rates in PE and PC patients were $16.7 \%$ and $26.7 \%$, respectively. It was observed that there was no statistically significant difference in this respect between the two groups (sig. $=0.165>p$-value $=0.05$ ) (Table 5).

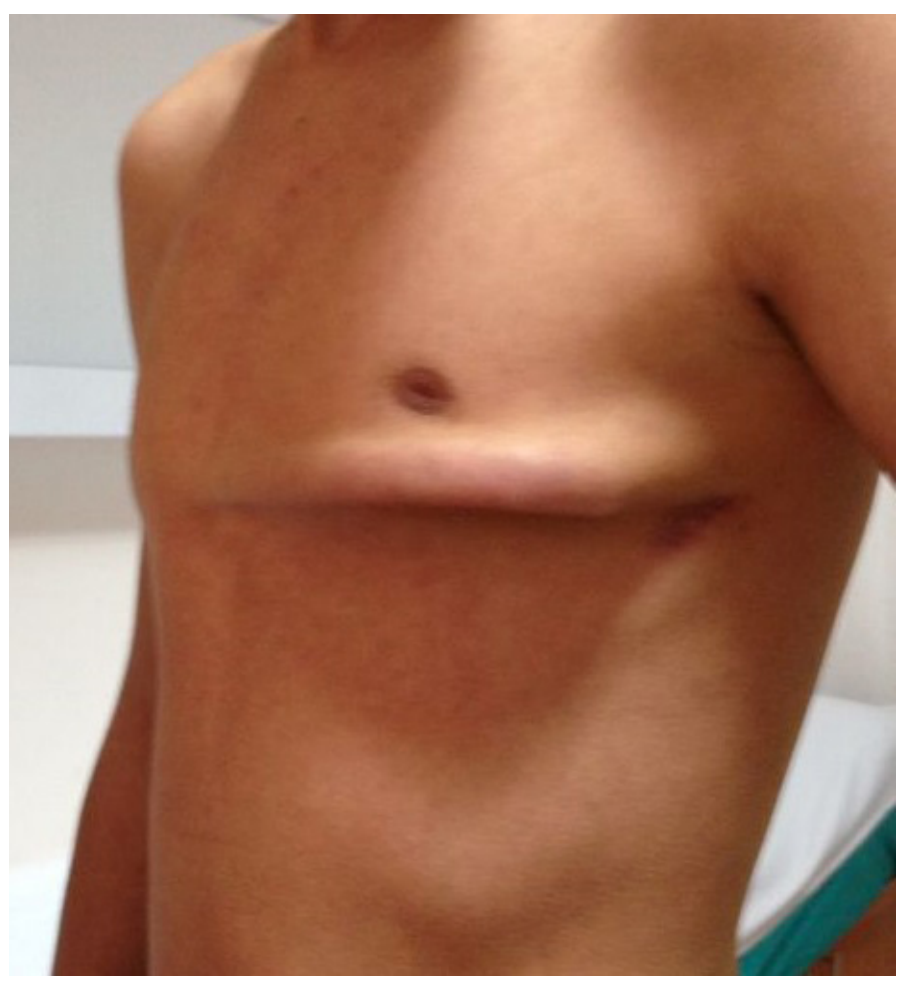

Figure 4. Bar dislocation and skin reaction due to metal bar in pectus carinatum.

Table 5. The statistical results of comperative groups.

\begin{tabular}{lccc}
\hline Statistical results & \multicolumn{3}{c}{ p-value } \\
\hline Complication rate & PE & PC & \\
Bar removal time (mean) & $16.7 \%$ & $26.7 \%$ & 0.165 \\
& $27.29 \pm 9.7$ & $16.89 \pm 9.5$ & 0.000 \\
& $\begin{array}{c}\text { with } \\
\text { complication }\end{array}$ & $\begin{array}{c}\text { without } \\
\text { complication }\end{array}$ & \\
Age (mean) & $17.61 \pm 4.81$ & $15.71 \pm 4.21$ & 0.040 \\
Haller index (mean) & $4.70 \pm 2.34$ & $3.47 \pm 1.34$ & 0.047 \\
Bar removal time (mean) & $17.17 \pm 12.28$ & $26.68 \pm 9.12$ & 0.001 \\
& asymmetric & symmetric & \\
$\begin{array}{l}\text { Symmetry of deformity } \\
\text { with complication }\end{array}$ & $22.4 \%$ & $17.6 \%$ & 0.474 \\
\hline (PE: pectus excavatum, PC: pectus carinatum, $\mathrm{p}$-value=0.05) & & \\
\hline
\end{tabular}




\section{DISCUSSION}

Preventing bar-related complications has been an important issue in our clinic to improve outcomes in these cases, since $78 \%$ of PE patients and $\% 100$ of PC patients are referred with aesthetic concerns. Since the mechanical principles of surgical correction techniques with the bar are similar, bar-related complications were considered in both patient groups in this study.

Many factors are determinant in the duration of hospital stay after surgery. Factors such as the patient's pain, delay in mobilization, adaptation process, and early complications can prolong this period. However, age is a parameter that is known preoperatively and can be taken precautions. Pawlak et al. reported that although minor complications and surgical morbidity are less common in PE under 15 years of age, overall cosmetic results are similar in all age groups. ${ }^{[4]}$

In this study there is no statistically significant correlation between age and bar removal time. This suggests that although the complications encountered increase as the age increases, the correction of the deformity makes the surgery acceptable and the bar is not removed until the planned time.

The complication and hospitalization time increased as the age increased in PE and PC cases. It is thought that the flexibility of the thorax decreases with the increasing age and the adaptation period is prolonged as a result of ossification.

It was observed that the symmetry of the deformity was not associated with complication rates. It has been recommended to be careful in terms of intraoperative and postoperative complications in cases of PE and PC with asymmetric deformity. ${ }^{[5,6]}$ In another study, no difference was found in complication rates between symmetrical and asymmetrical deformities. [7] We think that the complication rate does not increase in asymmetric deformities thanks to a series of technical details applied in our clinic.

The mean Haller index of the cases included in this study was $3.67 \pm 1.6$. It was found that as the Haller index increased in patients with $\mathrm{PE}$, the rate of postoperative complications increased. This is because the Haller index is parallel to the severity of the pectus deformity. Garzi et al. found fewer complications in patients with moderated PE in their study, in which they compared deformity severity and complication rates determined by the Haller index..$^{[7]}$ Postoperative complications can be predicted by the value of the Haller index.

When the complication and bar removal time were compared, it was observed that the duration of bar removal was shorter in complicated cases. If a complication due to a bar is detected, this leads the surgeon to decide to remove the bar.

When all cases were evaluated, it was found that the duration of bar removal decreased as complications were seen. The reasons for bar removal before the end of the treatment period were directly related to the complications encountered.
After an operation performed with aesthetic concern, if a complication that requires a second operation is encountered, it will be appropriate to define it as a major complication. Surgical intervention was required in 21 of 28 complications detected due to bar-related reasons such as bar dislocation, bar rotation, migration, bar exposure, and chronic pain.

In our study, the overall complication rate was $19.8 \%$. The complication rate was $16.7 \%$ and $26.7 \%$ for PE and PC, respectively. When bar-related complications were examined in large case series, it was observed that the rate of bar-related complications for PE ranged from $2.3 \%$ to $69.1 \% .^{[1,4,8-10]}$ For PC, it was observed that there were complications related to bar with a rate of $19.8 \%-60 \% .{ }^{[11,12]}$ Compared to the literature, the complication rate in this study is at an acceptable level.

\section{CONCLUSION}

Attention to many technical details at every stage, from patient selection to the bar removing, has resulted in acceptable complication rates independent of the shape of the deformity. In addition to "modification of repair surgeries", which are frequently reported in the literature, "complication management" is an issue that is less discussed in the literature, but needs more emphasis because it affects patient morbidity.

\section{ETHICAL DECLARATIONS}

Ethics Committee Approval: Selcuk University Medical School Local Ethical Committee, Approval No: 2020/246.

Informed Consent: Because the study was designed retrospectively, no written informed consent form was obtained from patients.

Referee Evaluation Process: Externally peer-reviewed.

Conflict of Interest Statement: The author(s) declared no potential conflicts of interest with respect to the research, authorship, and/or publication of this article.

Financial Disclosure: The authors declared that this study has received no financial support.

Author Contributions: All of the authors declare that they have all participated in the design, execution, and analysis of the paper, and that they have approved the final version.

\section{REFERENCES}

1. Nuss D, Kelly RE Jr, Croitoru DP, Katz ME. A 10-year review of a minimally invasive technique for the correction of pectus excavatum. J Pediatr Surg 1998;33(4):545-52.

2. Abramson $\mathrm{H}$. A minimally invasive technique to repair pectus carinatum Preliminary report. Arch Bronconeumol 2005;41:349-51.

3. Kuru P, Cakiroglu A, Er A, et al. Pectus Excavatum and Pectus Carinatum: Associated Conditions, Family History, and Postoperative Patient Satisfaction. Korean J Thorac Cardiovasc Surg 2016;49(1):29-34.

4. Pawlak K, Gąsiorowski Ł, Gabryel P, Gałęcki B, Zieliński P, Dyszkiewicz W. Early and late results of the Nuss procedure in surgical treatment of pectus excavatum in different age groups. Ann Thorac Surg 2016;102(5):1711-6.

5. Hebra A, Kelly RE, Ferro MM, Yüksel M, Campos JRM, Nuss D. Life-threatening complications and mortality of minimally invasive pectus surgery. J Pediatr Surg 2018;53(4):728-32. 
6. Abramson H, Aragone X, Blanco JB, Ciano A, Abramson L. Minimally invasive repair of pectus carinatum and how to deal with complications. J Vis Surg 2016;2:64.

7. Garzi A, Prestipino M, Rubino MS, Di Crescenzo RM, Calabrò E. Complications of the "Nuss Procedure" In Pectus Excavatum. TransI Med UniSa 2020;22:247.

8. Castellani C, Schalamon J, Saxena AK, Höellwarth ME. Early complications of the Nuss procedure for pectus excavatum: a prospective study. Pediatr Surg Int 2008;24(6):659-66.

9. Park HJ, Kim KS. Pectus bar removal: surgical technique and strategy to avoid complications. J Vis Surg 2016;2:60.

10. Goretsky MJ, Kelly RE Jr, Croitoru D, Nuss D. Chest wall anomalies: pectus excavatum and pectus carinatum. Adolesc Med Clin 2004;15(3):455-71.

11. Yuksel M, Lacin T, Ermerak NO, Sirzai EY, Sayan B. Minimally invasive repair of pectus carinatum. Ann Thorac Surg 2018;105(3):915-23.

12. Abramson H, D'Agostino J, Wuscovi S. A 5-year experience with a minimally invasive technique for pectus carinatum repair. J Pediatr Surg 2009;44:11823. 